\title{
TIME AND RATE OF LOSS OF NUCLEI BY THE RED BLOOD CELLS OF HUMAN EMBRYOS
}

\author{
ELIZABETH L. THOMPSON \\ Department of Anatomy, Eniversity of Michigan, Ann Arbor \\ ONE FIGURE
}

It has long been known that the earliest red corpuscles appearing in the circulating blood of young human embryos contain a nucleus. It has, also, been recognized that in older embryos non-nucleated red blood cells begin to appear in the heart and peripheral vessels, a condition effected, as in the adult, by the loss of the nuclei from existing cells. Many embryologists have noted the gradual change from this full compliment of nucleated red blood corpuscles in the young embryo to the late fetal condition of total or practically total loss of nuclei from these cells. Minot (in Keibel and Mall, '12) reports that a considerable number of non-nucleated red blood cells were found in an embryo of two months, that this number increased consistently through the third month, and that at 8 months the majority of the corpuseles were non-nucleated. Maximow ('27), Knoll ('29), Weintrobe and Schumaker ('36), Bloom ('38) and Bloom and Bartelmez ('40) and others discuss the histology of the hematopoietic centers and the various phases of blood development, including the fact that the red corpuscles in the early embryo are nucleated and that the later cells lack a nucleus. Specific information relative to the time and rate of the loss of nuclei from these cells is not given.

Most of the authors of recent textbooks of embryology give little information as to the time when the loss of nuclei begins. Some fail even to mention it. Hamilton, Boyd and Mossman ('45) state only that the nuclei are extruded; Arey 
('46) states that the non-nucleated red cells are first formed during the second month and that during the third month non-nucleated corpuscles first predominate. Jordan and Kindred ('48) state merely that in the human embryo nonnucleated erythrocytes are present late in the second month. Patten ('46) is somewhat more explicit as to the time of nuclear loss, having requested for citation some of the preliminary data on which this work is based. Two fairly definite time elements thus appear to have been established by previous workers, (1) that the loss of nuclei by the red blood cells begins to be evident during the second month in the human embryo and (2) that few nucleated red cells are found by the middle of the third month of intra-uterine life. The rate of loss of nuclei appears to be undetermined.

It became a matter of interest, therefore, to attempt to determine more precisely the age at which non-nucleated red cells first appear, the rate of increase of these cells, and the time at which the nucleated red cells disappear from the fetal circulation. To accomplish this end, red blood cell counts were made in 71 specimens from the Human Embryo Collection of the Anatomy Department of the University of Michigan Medical School. The embryos and fetuses used range in estimated age, from the beginning of the 5th week $(5 \mathrm{~mm})$ to the 24 th week $(220 \mathrm{~mm})$ (tables 1 and 2) and included all of the material in the collection which was sufficiently well preserved to make cell counts possible. Where conditions permitted a reasonable degree of accuracy, counts were made in the right atrium, in the aorta, and in a large vein, usually one of the cardinals. Ten counts of 100 cells each were made from each of these regions. As a check on such routine counts, a sufficient number of samplings were made from smaller peripheral vessels to make certain there was no significant difference in the proportion of nucleated cells from internal as compared with more peripheral regions. This check was considered important because in some of the older fetuses, sectioned for regional study, only peripheral vessels were available. Wherever possible both arterial and 
TABIAF 1

Tabulated data relative to the loss of nuclei by red blood corpuscles in human enbryos auring the period of most rapid change

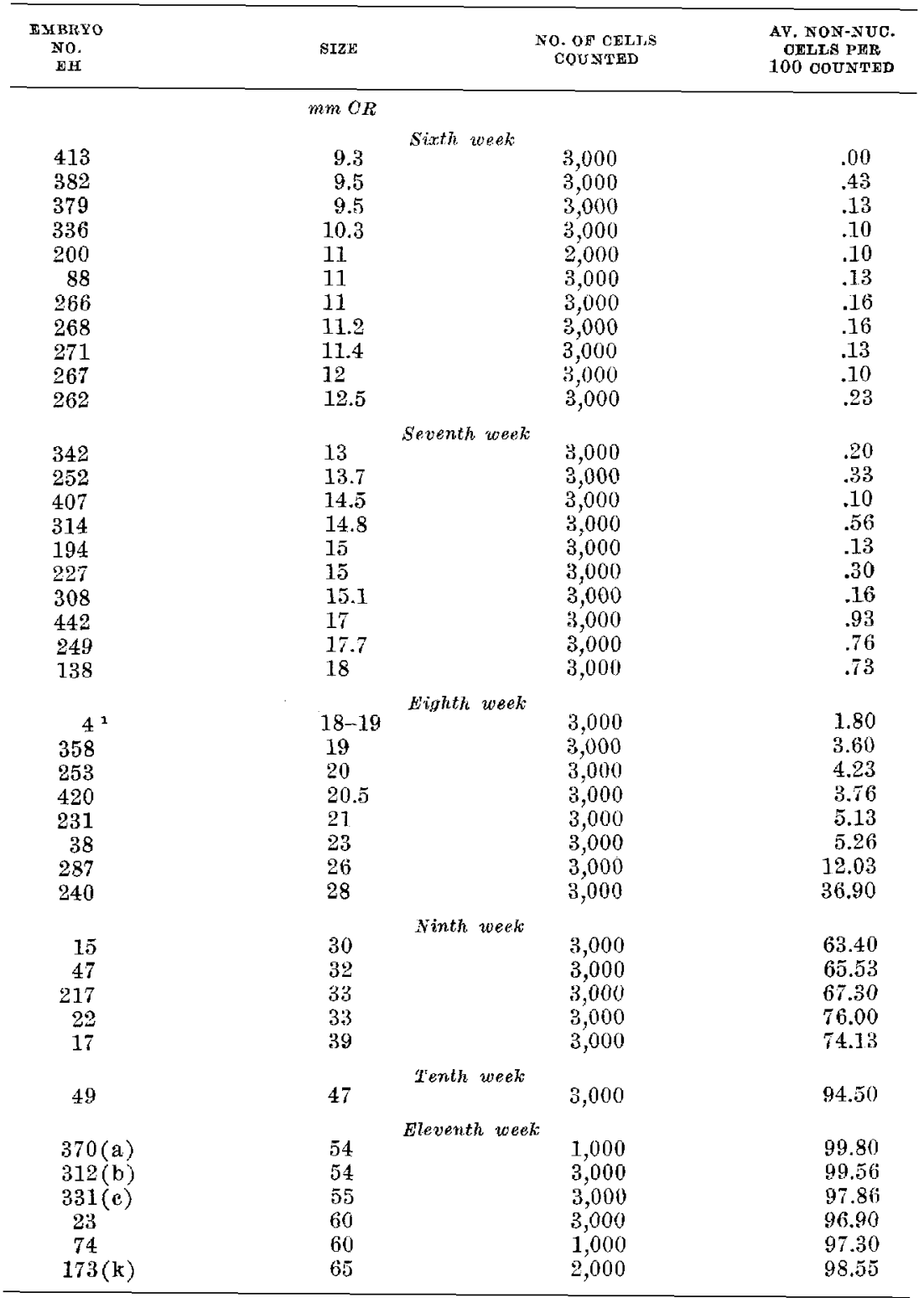

1 Adjusted age. 
venous vessels were used although the records show no appreciable difference in the cells from the two regions. Because of the known hematopoietic activity within the embryonic liver, no red cell counts were made from that area. Since the work here reported was concerned only with the time and rate of nuclear loss from the red blood cells, all cells encountered in the line of count, believed to be leucocytes were excluded from the results. After making a number of counts, involving around 300 cells for each embryo, the results appeared significant enough to suggest the desirability of assembling them in the form of a graph. Such a graph based on the averages resulting from counting large numbers of cells in as many embryos of different ages as were available, should not only show the rate of nuclear loss but, during the period of active loss, it might also prove of value in estimating the approximate age of embryo fragments for which the usual methods were not feasible.

The counts used in constructing the tables and the graph ranged from 1,000 to 3,000 blood cells for each embryo having blood well enough preserved to permit counting. The larger number $(3,000)$ was obtained wherever possible. The total number of cells counted in the 71 embryos used was 183,000 (table 2). Certain precautions were taken in order to insure greater accuracy in the results: (1) where possible 1,000 cells were counted from each of three different areas in the embryo: (2) cells were counted from alternate sections in each series, in order to avoid the chance of counting some of the same cells twice as might occur in counting cells cut in sectioning and thus appearing in consecutive sections; (3) relatively large numbers of cells $(1,000$ to 3,000$)$ were counted from different areas in each embryo or fetus in order to reduce the errors involved in the non-uniform distribution of nucleated and non-nucleated cells or plastids; (4) the averages used (table 1) in plotting the curve, were based on the total number of cells counted $(1,000$ to 3,000$)$ in each embryo; (5) as a further attempt to reduce errors, an oceasional cmbryo was recounted after having been put aside for a time, 
these recounts were close enough to the originals to indicate that there had been no significant errors in the counts as a whole; (6) the embryos used for counting were not arranged in chronological sequence but were selected at random and the age range relations of the results obtained were not correlated until a later date.

\section{TABLE 2}

Condensed data relative to the loss of nuclei by red blood corpuscles in all embryos used in this study

\begin{tabular}{|c|c|c|c|}
\hline $\begin{array}{l}\text { DEVHLOPMENTAL } \\
\text { AGE }\end{array}$ & $\begin{array}{c}\text { NUMBER OF } \\
\text { HMBRYOS USED }\end{array}$ & $\begin{array}{l}\text { TOTAL NUMBER OF } \\
\text { CEILS COUNTED }\end{array}$ & $\begin{array}{c}\text { AV. NON- } \\
\text { NUCLEATED CHLLS } \\
\text { PER } 100 \text { COUNTED }\end{array}$ \\
\hline 5th week & 6 & 12,000 & .00 \\
\hline 6th week & 16 & 46,000 & .09 \\
\hline 7th week & 10 & 30,000 & .42 \\
\hline 8th week & 8 & 24,000 & 9.09 \\
\hline 9th week & 5 & 15,000 & 69.23 \\
\hline 10th week & 1 & 3,000 & 94.50 \\
\hline 11th week & 6 & 13,000 & 97.81 \\
\hline 12th week & 1 & 2,000 & 97.70 \\
\hline 13th week & 2 & 5,000 & 99.25 \\
\hline 14th week & 6 & 13,000 & 99.27 \\
\hline 15 th week & 2 & 4,000 & 99.97 \\
\hline 16th week & 1 & 1,000 & 98.40 \\
\hline 17 th week & 2 & 4,000 & 99.70 \\
\hline 18th week & 1 & 2,000 & 99.95 \\
\hline 19 th woek & 2 & 4,000 & 99.82 \\
\hline 22 nd week & 1 & 3,000 & 99.90 \\
\hline 24th week & 1 & 2,000 & 99.80 \\
\hline Totals & 71 & 183,000 & \\
\hline
\end{tabular}

The embryos used were catalogued according to C.R. measurements taken at the time of receipt (usually shortly after fixation). For the purposes of this work, these measurements have been interpreted in terms of weeks (fertilization age) with the aid of the table and curves in Patten's Human Embryology ('46) pp. 184-185. All such measurements are, of course, subject to minor errors and these may well account for some of the variations in the cell counts. One such discrepancy was so marked (FII 4, $15 \mathrm{~mm}$ ) that the sections 
were checked for age with data recorded by Streeter ('48). Using his criteria, this embryo was judged to be older than the catalogued measurement indicated. As a further check, measurements of the sectioned embryo were made as suggested by Patten and Philpott ('21). Allowing for shrinkage due to fixation, these measurements suggested an older embryo. The results of these two checks together with the condition of nucleation of the red blood corpuscles indicated a measurement of $18-19 \mathrm{~mm}$ and this adjusted age (from the 7 th week to early in the 8 th week) has been used in the records given here (tables 1 and 2). It is interesting to note that the cheek methods used were in reasonable agreement suggesting that the condition of nucleation of the red blood cells may be used to approximate the age of embryos during the period when nuclear loss is progressing rapidly (7th through 10th week) (fig. 1).

In the entire course of the work no non-nucleated cells were observed in embryos of less than $9 \mathrm{~mm}$ C-R. A very few, that is an average of about $0.1 \%$, appeared in the 6th week. Embryos in the 7 th week of development showed a slight rise in the number of non-nucleated red blood cells, the average being about $0.5 \%$. This number began to increase rapidly during the 8th week, by the end of which the non-nucleated red cells had risen to $9 \%$. The most rapid change occurred in embryos during the 9 th week of development. At the end of this week the non-nucleated cells have reached an average of $69 \%$, an increase of $60 \%$ over embryos at the end of the 8th week. Embryos in the 10th week of development showed a further average increase of $25 \%$ in non-nucleated red blood cells, so that by the end of that week the average count was about $94 \%$ of non-nucleated cells. By the 11th week when the average number of non-nucleated corpuscles was $97.8 \%$, the changes in the average number of anucleate red blood cells became negligible, reaching a final $99.8 \%$ non-nucleated red cells in the 24th week (table 2).

The graph plotted from the data in table 1 and based directly on the average increase in nuclear loss per week, shows 
vividly the relatively slow loss of nuclei from the red blood cells between the 6th week and late in the 7 th week, which is followed by a more marked change in the nuclear condition between the latter part of the 7 th and the 8 th weeks. The

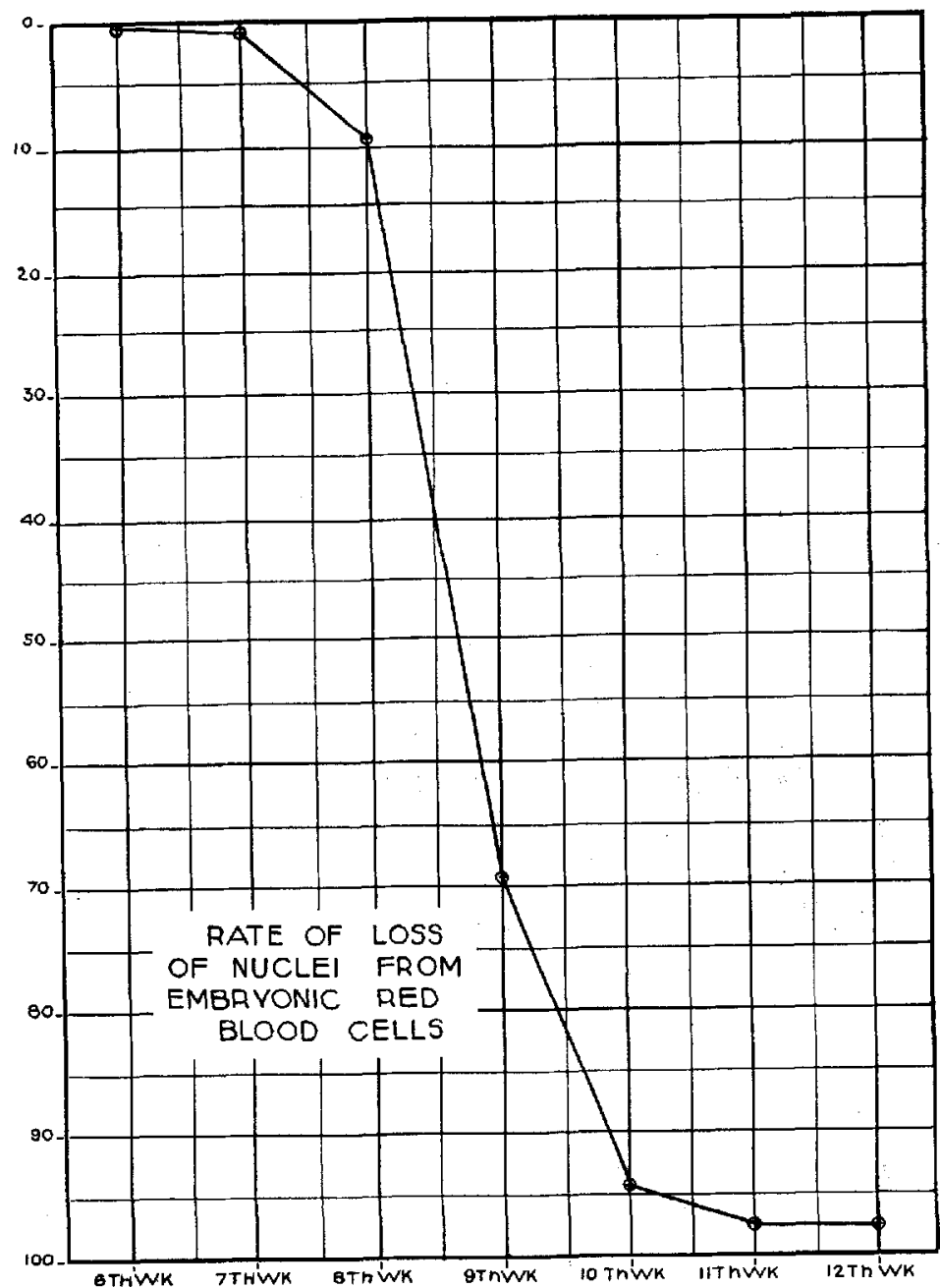

Fig. 1 Graph showing the rate of loss of nuclei by red blood corpuscles in human embryos during the period of most rapid change. The vertical axis shows the average number of non-nueleated red blood corpuscles per 100 for embryos in the age groups indicated on the horizontal axis. It is based on data recorded in table 1 . 
period of pronounced loss extends into the 10th week. In the next two weeks the rate of loss slows abruptly. Beyond this period the averages were not plotted. As was shown in table 2 there was little variation from then until the 24th week. Although the ages of the embryos used are not as uniformly distributed in the entire group as one might wish, it is believed that the total number (71) of embryos used (table 2) is sufficiently large to give the recorded data (table 1) some significance. The relatively large number of cells $(1,000$ 3,000 ) counted for each embryo aids in reducing errors in the counts averaged and used in plotting the curve.

It is believed that this curve, which indicates the weekly rate of nuclear loss by the red blood corpuscles in human embryos, will prove to be of value in determining the age of certain embryos which have been inadequately or inaccurately measured. It will also add another factor useful in determining the developmental stages of human embryos as described by Streeter ('45, '48). It is quite possible that the data and graph might prove of value in estimating the age of embryos too fragmented, or otherwise multilated, to permit the making of accurate measurements or the study of the developmental characteristics used by Streeter. Enough blood in an embryonic fragment, sufficiently well preserved so that nucleated and non-nucleated cells could be distinguished, would be all that was required to fix age fairly accurately in the case of embryos in the periods of rapid nuclear loss.

\section{LITERATURE OITED}

Arex, Leslie B. 1946 Developmental anatomy. ix +616 pp. W. B. Saunders Co., Philadelphia.

BLook, WILLIAM 1938 Erythrogenegis of mammalian blood. In Handbook of hematology, Hal Downey, editor. W. B. Saunders Co., Philadelphia, 2: $865-922$.

Bloom, William and G. W. Bartelmez 1940 Hematopoiesis in young human embryos. Am. J. Anat., 67: 21-53.

Hamilton, W. J., F. D. Boyd ANd H. W. Mossman 1945 Human embryology. viii +366 pp. The Williams and Wilkins Co., Baltimore.

Jordan, Harvey E., AND JAMES E. KINDRed 1948 Textbook of embryology. xiv +613 pp. D. Appleton-Century Co., New York. 
KNouL, W. 1929 Untersuchungen über embryonali Blutbildung beim Menchen. Jahr 6. Morph. u. mikrosk. Anat., Abt. 2. Zeitschr. Mikrosk. Anat. $18\left(\frac{1}{2}\right): 199-232$.

Maximow, A. 1927 Bindegewebe und blutbildende Gewebe. Handbuch. d. mikr. Anat. d. Menschen. (v. Möllendofi), Berlin, 2: 232.

Mino', C. S. 1912 In Manual of Human Embryology by Keibel and Mall. J. B. Lippincott Co., Philadelphia, 2 : 498-534.

Pattes, Bradley, M. 1946 Human embryology. $x v+776$ pp. Blakiston Co., Philadelphia.

Patten, Bradley M., and Reks Philport 1921 The shrinkage of embryos in the processes preparatory to sectioning. Anat. Rec., 20: 4, 393-413.

STREETER, G. L. 1945 Developmental horizons in human embryos. Age groups XIII and XIV. Carnegic Contrib, to Embryol., 31: 29-63. 1948 Developmental horizons in human embryos. Age groups XVXVIII. Carnegie Contrib. to Embryol, 39: 133-203.

WinTrobe, M. M. 1936 Erythrocyte studies in the mammalian fetus and newborn. Am. J. Anat., 58: 313-328. 